\title{
Late Viséan coral fringing reef at Tiouinine (Morocco): implications for the role of rugose corals as building organisms in the Mississippian
}

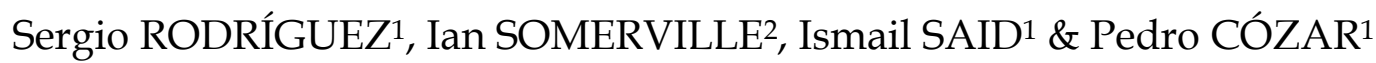

\author{
${ }^{1}$ Departamento y U.E.I. de Paleontología. Instituto de Geociencias de Madrid y Facultad de Ciencias \\ Geológicas, CSIC-UCM, c/José Antonio Novais, 2, 28040 Madrid, Spain; sergrodr@geo.ucm.es \\ ${ }^{2}$ UCD School of Geological Sciences, University College Dublin, Belfield, Dublin 4, Ireland; \\ Ian.Somerville@ucd.ie
}

Coral reefs have been regarded as being scarce or absent in Mississipian times (NEWELL 1972; COPPER 1988). Large structured reefs in the Mississippian have been built mainly by calcareous algae (Wolfenden 1958) or Chaetetids (NAGAI 1985). In some of those instances, corals played a secondary role (ADAMS 1984). Recent works have demonstrated the existence of patch reefs and reefal structures where corals were the main, but not the unique buildings organisms (RODRíGUEZ et al. 1994; ARETZ 2002; ARETZ \& HERBIG 2003, SOMERVILLE \& RODRÍGUEZ 2007). But either complete structure of reefs was not preserved or reefs did lack such a structure.

However, a Mississippian fringing reef with excellent preservation and showing a coral framework is located at Tiouinine, near Khenifra (Central Moroccan Meseta). The excellent preservation of that reef is due to lack of main tectonic alterations in the zone and to a selective erosional preservation that eliminated the superimposed Mesozoic sediments, but preserved the Mississippian rocks.

The reefal facies rest directly on Devonian sandstones. There is a complete zonation from tidal deposits to reefal talus. Tidal deposits occur in a narrow band and are composed of sandy packstones. There is a transition to reef flat deposits composed of packstones-grainstones with patchy distribution of coral colonies. Fasciculate corals of the genera Siphonodendron and Tizraia are dominant there. Also a transitional change to core reef facies is shown at the field outcrops (Fig. 1).

The core reef facies are composed of fasciculate and massive corals reinforced by algal masses around corals and microbial micropeloidal mudstone to wackestone coating the corals and algae. The spaces between corals and algal masses are infilled by crinoidal and coral grainstone. Dominant building organisms are corals of the genera Siphonodendron, Lithostrotion, Diphyphyllum and Tizraia. But diversity is quite high; colonies of genera Palastraea, Michelinia and Syringopora are also common, and solitary corals are diverse and abundant (Axophyllum, Gangamophyllum, Pareynia, "Amplexus", Clisiophyllum, Arachnolasma, Koninckophyllum, Aulokoninckophyllum, Palaeosmilia, Kizilia, Haplolasma, Semenoffia, etc.). Some chaetetids also occur in the reef core.

The proximal talus is represented by packstones and rudstones containing highly diverse bioclasts, corals, crinoids, foraminifers, gastropods, bivalves, etc., large fragments of reworked coral colonies and some coral colonies in growth position. These beds show erosive surfaces and amalgamation of beds. A somewhat distal talus is located at south, and it is represented by well-bedded marly limestones containing mainly crinoids and branches of fasciculate corals.

The existence of the Tiouinine reef is an evidence of that Mississippian corals had the potential to built large structured reefs. The rarity of these structures may be related to the tectonic and climatic instability. 


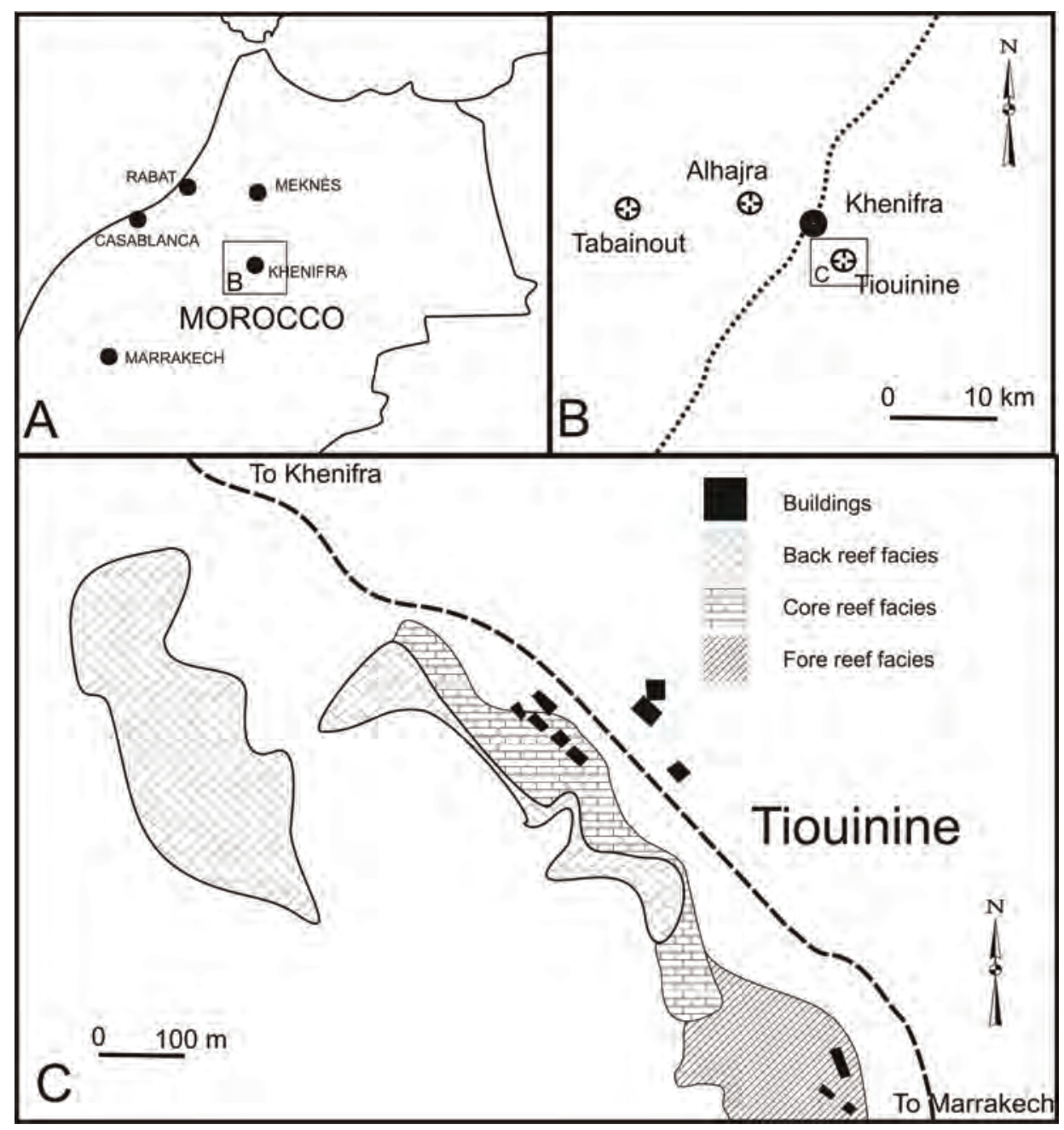

Fig. 1: Location and distribution facies in the Tiouinine reef. A.- Location of the Khenifra area. B.- Location of the Tiouinine reef in the Khenifra area. C.- Distribution of facies in the Tiouinine reef.

ADAMS, A. (1984): Development of algal-foraminiferal-coral reefs in the Lower Carboniferous of Furness, northwest England. - Lethaia, 17: 233-249.

ARETZ, M. (2002): Habitatanalyse und Riffbildungspotential kolonialer rugoser Korallen im Unterkarbon (Mississippium) von Westeuropa. - Kölner Forum für Geologie und Paläontologie, 10: 1-155.

AretZ, M \& Herbig, H.-G. (2003): Coral-rich bioconstructions in the Viséan (Late Mississippian) of Southern Wales (Gower Peninsula, UK). - Facies, 49: 221-242.

COPPER, P. (1988): Ecological succession in Phanerozoic reef ecosystems: is it real? - Palaios, 3: 136-151.

NAGAI, K. (1985): Reef forming Algal Chaetetid boundstone found in the Akiyoshi Limestone Group, Southwest Japan. - Bulletin of the Akiyoshi-Dai Museum for Natural History, 20: 1-15

NEWELL, N.D. (1972): The evolution of reefs. - Scientific American, 226(6): 54-65.

Rodríguez, S, ARribas, M.E., Moreno-Eiris, E \& De la PeÑA, J.A. (1994): The Siphonodendron Limestone of the Los Santos de Maimona Basin: development of an extensive reef-flat during the Viséan in Ossa Morena, Spain. - Courier Forschunginstitut Senckenberg, 172: 203-214.

SOMERVILlE, I.D. \& RodRíGUEZ, S. (2007): Rugose coral associations from the Upper Viséan of Ireland, Britain and SW Spain. - In: Hubmann, B. \& PIller, W.E. (Eds.), Fossil Corals and Sponges, Proceedings of the 9th International Symposium on Fossil Cnidaria and Porifera, Graz, 2003. Austrian Academy of Sciences, Schriftenreihe der Erdwissenschaftlichen Kommissionen, 17: 329-351.

WolfEndEN, E.B. (1958): Palaeoecology of the Carboniferous reef complex and shelf limestones in northwest Derbyshire, England. - Geological Society of America Bulletin, 69: 871-898. 